\title{
Review of Mrinali C. Clarke, the ever- transcending quest: a literary analysis of the poetry of Sri Chinmoy (D. K. Printworld, 2015)
}

Kusumita P. Pedersen

Correspondence: kusumita@igc.org St. Francis College, 165-20 Chapin Court, Jamaica, NY 11432, USA
Keywords: Bengali; Chinmoy; Dickinson; Poetry; Quest; Spiritual; Transcendence; Whitman

Clarke, Mrinali C. Foreword by Purushottama Bilimoria.

The Ever-Transcending Quest: A Literary Analysis of the Poetry of Sri Chinmoy

New Delhi: D. K. Printworld; 2015

149 pages, ISBN 13: 978-81-246-0802-9

This slim volume is an excellent and engaging gateway into the poetry of Sri Chinmoy (1931-2007), who is better known as a spiritual teacher and philosopher who innovatively used the arts and athletics to convey a message of peace and transformation. $\mathrm{He}$ wrote thousands of poems in both English and Bengali, but so far secondary works on this extensive corpus are few. Clarke's book is thus a welcome contribution. The interpretive and organizing structure of "the quest," she says, emerged naturally as she read through Sri Chinmoy's voluminous poetic oeuvre and her study demonstrates the validity of this approach.

In her introduction Clarke connects Sri Chinmoy to a tradition of poets writing in English on spiritual themes, including George Herbert, William Wordsworth, Walt Whitman and Emily Dickinson, as well as the American Transcendentalists Ralph Waldo Emerson and Henry David Thoreau. She identifies as central questions concerning Sri Chinmoy's poetry the problem of giving words to the ineffable and how the most marked formal feature of Sri Chinmoy's poems - their brevity and highly condensed mode of expression - is intrinsically related to their content. Clarke helpfully calls this brevity a "distilled" quality, in which each word bears concentrated meaning while the poetry still appears simple. This mode of expression is deliberately designed by the poet to bypass the discursive mind and directly reach intuition and "the heart," which figures prominently in his philosophy.

In the next three chapters Clarke discusses how Sri Chinmoy's poetry portrays the human journey to the Divine. She construes "the quest" as three unfolding phases: "The Separation," in which the soul departs from its Source and enters this world, "The Trial," in which the seeker experiences suffering, doubt, and adversity, and "The

(c) 2016 The Author(s). Open Access This article is distributed under the terms of the Creative Commons Attribution 4.0 International License (http://creativecommons.org/licenses/by/4.0/), which permits unrestricted use, distribution, and reproduction in any medium, provided you give appropriate credit to the original author(s) and the source, provide a link to the Creative Commons license, and indicate if changes were made. 
Return," in which the mature mystic attains intimacy with the Divine and at last Godrealization, or complete conscious union with the supreme Self. This goal of realization is not final, but is followed by "God-manifestation" or transformation of the world, which is "ever-transcending," hence the book's title.

Clarke has made a wonderful selection from Sri Chinmoy's poetry, especially considering the need to choose from thousands of poems, even though she has limited herself mostly to works he wrote from his youth in India though the mid-1970s. She includes both those written in English and Sri Chinmoy's own translations of his Bengali lyrics. (The originals have been included for some, but not all, of these translations and one wishes that the Bengali had been included in every case.) The poems as arranged vividly illustrate the overarching narrative of the quest. The reader will derive a sense of Sri Chinmoy's unique voice, style and vocabulary while traveling through the myriad joys, sorrows, perplexities and even humor of the voyage. As in the introduction, illumining comparative references to other poets are brought in as appropriate. One does miss, however, any discussion of Rabindranath Tagore, with whom Sri Chinmoy has a close affinity; this is a significant omission. Clarke gives skillful close readings of many of the poems showing their internal complexity in spite of their brevity. She has a finely attuned attention to sound, alliteration and rhythm with a grasp of metaphor and how the qualitative is related to structure and semantics. Sharing perceptive psychological insights, she rightly points out that the many different emotions expressed by Sri Chinmoy in his poetry do not constitute a personal "confession" in any usual sense and are not on an autobiographical trajectory. Rather they are diverse aspects, which the poet has entered empathetically, of the human experience of the spiritual journey. Clarke provides philosophical context as needed to elucidate the poems' content, and makes clear that she is an adherent of the philosophy expressed in the poems. She has achieved an effective fusion of literary analysis with her deep personal appreciation as a student of Sri Chinmoy. The volume concludes with a useful short biography of him.

This book can serve both as an inviting and informative introduction for those who do not know Sri Chinmoy's works and an enriching exploration for those who do. One hopes that a paperback edition may become available for use in college and university courses, for which this study is ideally suited. Let us also hope that Clarke will continue on and write a treatment of Sri Chinmoy's later poetry which, as she mentions, often differs considerably in style, as in his later years he pursued ever-increasing "distillation" of expression. With this book she has laid a solid foundation for future work to which we may look forward. 